\title{
Semiotika Logo Video Game The Last Story
}

\author{
Ryan Aditya Pratama Warndana \\ Program Studi Desain Komunikasi Visual \\ Fakultas Seni Rupa ISI Yogyakarta
}

\begin{abstract}
This research has a purpose to understanding The Last Story video game logo within perpective of semiotics and design of visual communication. The Last Story video game logo has a visual and verbal signs to communicate message about concept, root of thinking and philosophy of the game, whether it is game's storyline or Mist Walker as the game developer. Method that has been used is a qualitative descriptive with Triadic of Sumbo Tinarbuko as a frame of analytics technique.

There are signed-signifier by Ferdinand de Saussure, trichotomy of icon, index, symbol by Charles Sanders Pierce, and semiotic codes by Roland Barthes as a base theory to help to analyzing in this research. This research resulting in found of communication within the Last Story video game's logo has a subjective view, depend on the perspective and deep understanding of the audience, also the logo isn't always have to follow simplicity of commercial logo standarization.
\end{abstract}

Keywords: Semiotic, Logo, Video Game, The Last Story, Nitendo Wii, Visual Communication Design.

Relevance to Visual Communication Design Practice: Informasi singkat (15-25 kata) mengenai seberapa jauh dan aplikatif hasil penelitian untuk praktik disain komunikasi visual

\section{PENDAHULUAN}

\section{Latar Belakang Masalah}

Video game merupakan salah satu mesin listrik yang ditujukan untuk kebutuhan hiburan (entertainment) yang menggabungkan beberapa jenis hardware untuk dinikmati secara visual dan dioperasikan melalui tombol-tombol, sentuhan, atau lainnya. Kepopuleran video game pada kalangan anak-anak bahkan dewasa pada era 80'an menjadikan industri video game berkembang pesat. ${ }^{1}$

Pada video game sendiri, logo yang pertama kali digunakan adalah logo Bertie The Brain yang digunakan untuk game arcade pertama pada Pameran Nasional Kanada tahun 1950 dengan game-nya tic-tac-toe. Logo ini menjadi representasi untuk mesin game arcade yang ditampilkan. Sedangkan logo tertua paling populer yang digunakan pada video game adalah logo Atari

\footnotetext{
1 http://web.archive.org/web/20090226064943/http://ti me.com/time/covers/1101050523/console_timeline. Diakses: 16/05/2013, 12:14.
} 
perusahaan video game yang terkenal dengan game Pong pada tahun 1972. Logo tersebut didesain oleh George Opperman dan merepresentasikan huruf "A" yang di stylish (gaya), dengan dua garis yang merepresentasikan dua pemain video game yang saling berhadapan serta garis ditengah yang merepresentasikan pembatas pada permainan "pong". ${ }^{2}$

Nintendo sebagai salah satu perusahaan yang memproduksi video game sangat terkenal dengan konsolgenerasi ke-3 keluarannya yang bernama NES (Nintendo Entertainment System) pada era '90an. Kemudian digantikan dengan SNES (Super Nintendo Entertainment System) dengan gamenya yang sangat populer Super Mario Bros, namun sayang, keluarnya Sony Playstation, game konsol keluaran Nintendo seolah lenyap ditelan kepopuleran Playstation yang menyuguhkan visualisasi 3D. Barulah pada generasi ke-7 game konsol, pada tahun 2006 Nintendo mengeluarkan konsol game yang bersaing berat dengan Playstation 3 \& Xbox 360, yaitu Nintendo Wii dengan ciri khas Wii Remote \& Nunchaku yang

\footnotetext{
${ }^{2}$ http://www.logodesignlove.com/atari-logo. Diakses: 31/12/2014, 09:54.
}

memanjakan gamer (pemain video game) untuk bermain tanpa kabel. ${ }^{3}$

Pada masa-masa menjelang penutupan umur Nintendo Wii yang akan digantikan oleh Nintendo Wii U, pada tahun 2011 Nintendo mengusung game berjudul The Last Story yang dibuat oleh studio game Mist Walker, salah satu game RPG (Role Playing Game). ${ }^{4}$ Menariknya adalah, pada logo publikasi video game The Last Story ini memiliki sedikit kemiripan dengan ciri khas pada logo Final Fantasy, video game RPG buatan buatan Squaresoft (Kini Square Enix). Padahal Mist Walker dan Square Enix adalah studio game yang berbeda. Square Enix adalah gabungan perusahaan Square (Squaresoft) dan Enix pada tahun 2003 yang memiliki sejarah panjang kebelakang hingga tahun 1983 (Dibentuknya Square) dan 1975 (Dibentuknya Enix) (Square Enix, 2004:12), sedangkan Mist Walker baru dibentuk pada tahun $2004 .^{5}$

3 http://www.consolewatcher.com/2006/05/nintedorevolution-renamed-to-nintendo-wii/. Diakses: 16/05/2013, 23:15.

4 http://en.wikipedia.org/wiki/The_Last_Story. Diakses: 28/03/2014, 12:01

5 http://www.giantbomb.com/mistwalkercorporation/3010-6286/. Diakses: 28/03/2014, 15:22. 


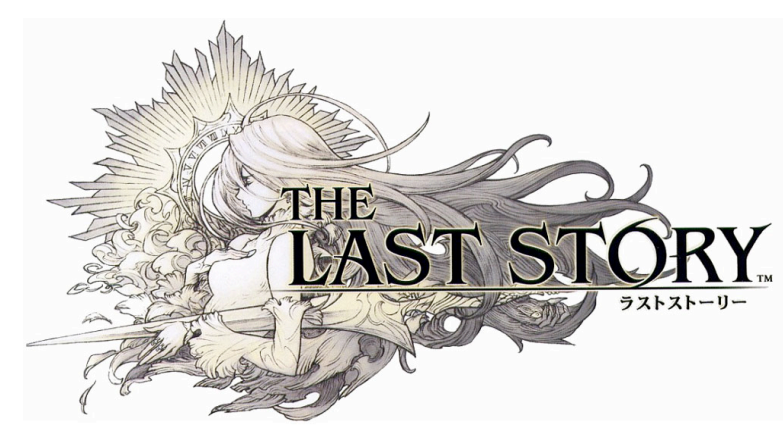

Gambar 1 Logo game The Last Story yang dipublikasikan oleh Mist Walker Sumber: http://mistwalkercorp.com, diunduh 06/02/2014, 17:44

Ternyata bukan hanya pada logo saja game The Last Story memiliki kemiripan dengan game Final Fantasy, secara simbolik pada logo kecenderungan penggunaan visualisasi karakter yang didukung dengan tipografi serta nama pada judul game dan model penceritaan pada game didalamnya ternyata juga memiliki nafas yang cukup mirip.

Penelitian ini sangatlah penting sebab selama ini studi terhadap logo memiliki kecenderungan teoretis bahwa logo haruslah sederhana/simpel, fleksibel dan unik (Rustan, 2009) dengan sedikit elemen didalamnya, namun dengan adanya logo game The Last Story ini seolah-olah menggeser kedudukan teori tersebut. Bukannya menggunakan logo yang sederhana, logo game The Last Story cukup rumit dengan cakupan-cakupan elemen ilustrasi di dalamnya. Nantinya dengan pemahaman makna konotasi pada logo melalui semiotika maka akan dapat diketahui makna-makna apa saja yang ada pada logo tersebut dan apakah logo tersebut memiliki kaitan emosional terhadap Final Fantasy sebagai game yang sebelumnya diliris oleh Hironobu Sakaguchi, serta secara tidak langsung dapat menguak alasan penggunaan logo dengan elemen yang cukup rumit.

Penelitian yang tersistematis, melalui pemahaman terhadap logo game The Last Story melalui jendela Desain Komunikasi Visual, diharapkan nantinya akan terkuak suatu cerita menarik tersendiri mengenai logo game The Last Story, sebab banyak pertanyaan mengenai apa maksud yang ingin disampaikan oleh developer (pengembang) game The Last Story pada saat menetapkan logo yang dipublikasikan tersebut kepada gamer sebagai target audience yang menjadi sasaran target utama dalam game tersebut. Nantinya penelitian akan berguna bagi berbagai kalangan yang berkaitan dengan kebutuhan terhadap ilmu desain komunikasi visual, baik secara teoretis maupun praktis.

\section{Rumusan Masalah}

Bagaimanakah memahami makna konotasi logo video game The Last Story dalam perspektif semiotika dan desain komunikasi visual? 


\section{Tujuan Penelitian}

Memahami makna konotasi logo video game The Last Story dalam perspektif semiotika dan desain komunikasi visual.

\section{Tinjauan Teori}

Teori yang digunakan dalam penelitian terdiri dari teori utama yaitu teori semiotika dan teori pendukung seperti teori Logo, Game dan Desain Komunikasi Visual.

Teori Utama: Semiotika merupakan teori yang digunakan sebagai pisau bedah teori utama, yang berfungsi mengungkap makna-makna dari tanda-tanda visual dan verbal yang ada. Teori semiotika yang digunakan dalam penelitian adalah teori Petanda-Penanda milik Ferdinand de Saussure, Trikonomi Ikon-Indeks-Simbol milik Charles Sander Pierce serta teori kodekode semiotika milik Roland Barthes.

Teori Pendukung: Teori logo digunakan sebagai sarana tinjauan terhadap objek penelitian yang berupa logo. Teori Game sebagai penuntun dalam melakukan analisis untuk pemahaman terhadap logo itu sendiri. Sedangkan teori Desain Komunikasi Visual seperti ilustrasi, nirmana, tipografi merupakan teori yang mendukung sebagai jembatan komunikasi yang ada antara logo dan audience.

\section{Metode Penelitian}

Metode penelitian yang dipergunakan dalam penelitian ini adalah metode penelitian kualitatif deskriptif. Menurut Moleong penelitian kualitatif adalah penelitian yang menghasilkan prosedur analisis yang tidak meggunakan prosedur analisis statistik atau cara kauntifikasi lainnya (Moleong, 2012:6). Metode pendekatan kualitatif menggunakan jenis/tipe deskriptif, dan apabila penelitian tersebut dilakukan dalam kurun waktu tertentu pada objek tertentu, maka hal tersebut dapat dikatakan sebagai studi kasus (Bungin, 2012:109-110).

Metode penelitian deskripsi sendiri merupakan prosedur pemecahan masalah yang diselidiki dengan menggambarkan atau melukiskan keadaan subjek atau objek penelitian berdasarkan fakta-fakta yang tampak atau sebagaimana adanya. Pada tahap awal berusaha mendeskripsikan fakta untuk mengemukakan gejala secara lengkap di dalam aspek penelitian, sehingga jelas pada adanya. Upaya mendeskripsikan fakta di lapangan tidak hanya pada pengumpulan dan penyusunan data, melaikan juga dengan analisis dan intepretasi tentang arti yang dikaitkan dengan teori yang dipakai sebagai alat analisis. (Nawawi, 2007:67), dengan demikian metode penelitian dengan pendekatan kualitatif adalah yang paling tepat 
dalam memahami makna logo game The Last Story, sebab pengkajian dapat memasuki hingga lapisa ide/konsep dari logo tersebut, tidak sekedar berhenti pada lapisan permukaan saja sehingga makna dibalik logo game The Last Story dapat dipahami secara lebih mendalam.

\section{PEMBAHASAN DAN HASIL PENELITIAN}

Pada penelitian ini, terdapat 6 populasi yang diambil dari variasi official (resmi) logo video game The Last Story, kemudian dari populasi tersebut diambil 3 sampel yang dipergunakan untuk mewakili populasi yang ada.

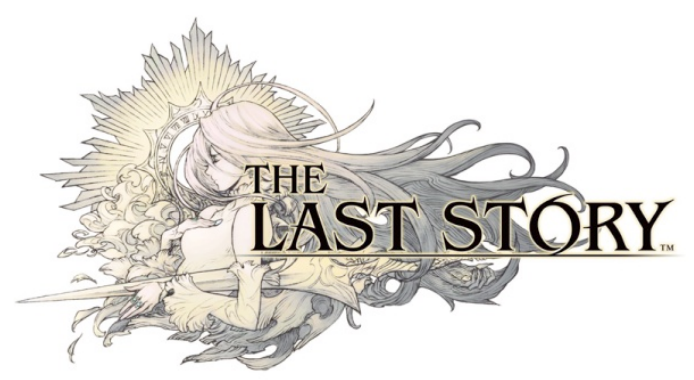

Gambar 2 Logo publikasi video game The Last Story oleh perusahaan Mist Walker Sumber: www.creativeuncut.com, diunduh: 16/02/2013, 12:06

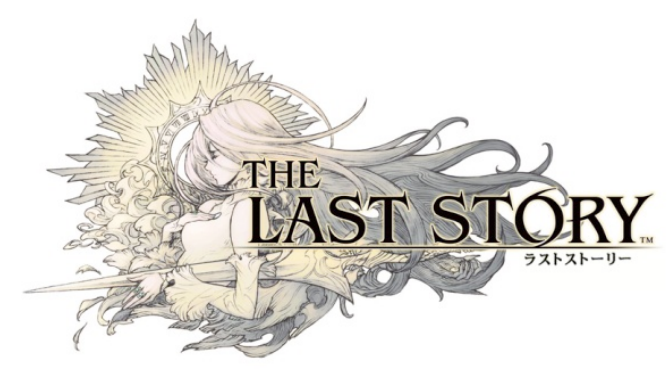

Gambar 3 Logo publikasi video game The Last Story Versi Jepang

Sumber: www.mistwalker-fr.info, diunduh: 28/02 2014, 04:50.

\section{LAST STORY}

Gambar 4 Logo Cover

Dalam analisis data yang ada sampel kemudian dianalisis dengan metode deskriptif kualitatif. Secara khusus, dalam penelitian ini akan menggunakan teknik analisis Triadik Sumbo Tinarbuko (2006) yang dianggap efektif dalam menganalisis objek penelitian dengan teori semiotika.

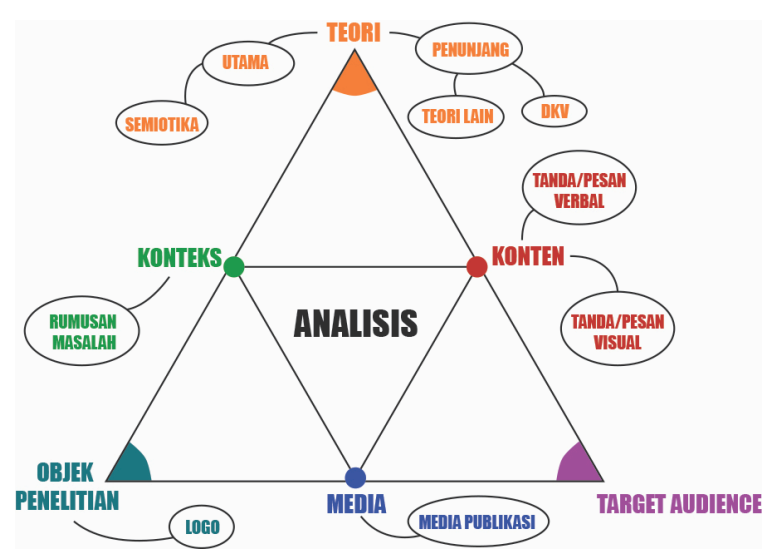

Gambar 5 Triadik Sumbo Tinarbuko (2006)

Analisis ini menjadi efektif karena objek penelitian adalah berupa logo yang merupakan salah satu bagian dari karya desain komunikasi visual, sedangkan tujuan penelitiannya adalah untuk dapat memahami objek tersebut menggunakan teori semiotika. 
Pada saat meninjau suatu karya desain, analisis semiotika komunikasi visual dengan menggunakan Triadik Sumbo Tinarbuko tentunya perlu melalui langkah-langkah tertentu untuk mendapatkan hasil analisis yang baik. Dalam buku Semiotika Komunikasi Visual, analisis semiotika komunikasi visual melalui tiga proses, yaitu proses identifikasi, deskripsi, serta intepretasi (Tinarbuko, 2008):

1) Proses Identifikasi: Sampel objek penelitian terpilih dari populasi disajikan dan diidentifikasi sehingga dapat diketahui bagian-bagian yang akan dianalisis. Proses identifikasi ini menggunakan alat bantu berupa instrumen penelitian demi memperoleh data yang dibutuhkan secara presisi.

2) Proses Deskripsi: Bagian-bagian objek penelitian dari sampel terpilih kemudian disajikan ulang baik visual dengan cara layout ulang objek penelitian, maupun verbal menggunakan teks yang berisi deskripsi-deskripsi hasil identifikasi.

3) Proses Intepretasi: Bagian yang telah disajikan kemudian diintepretasikan dengan teori terkait yang ada sehingga hasil analisis terhadap data akan menghasilkan suatu kesimpulan yang bersifat objektif.

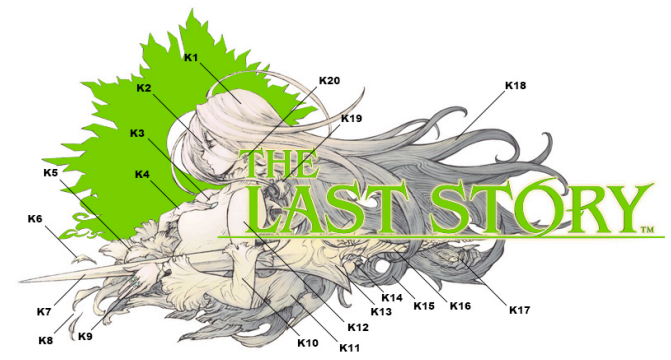

Gambar 6 Contoh identifikasi untuk dideskripsikan

Hasil dari proses identifikasi dan deskripsi yang ada kemudian dibuat intepretasinya berdasarkan data-data yang ada dilapangan sesuai dengan metode yang digunakan. Hasil proses intepretasi yang ada pada tiap sampel, kemudian dibuat kesimpulannya.

Pada penelitian yang berjudul "Semiotika Logo Video Game The Last Story" ini, telah dilakukan suatu analisis visual demi memahami makna konotasi yand ada pada logo tersebut dalam perspektif semiotika dan desain komunikasi visual. Pendekatan analisis yang dilakukan secara kualitatif deskriptif ini meminjam dasar teori semiotika yang dikemukakan oleh Ferdinand de Saussure mengenai petanda dan penanda, teori semiotika yang dikemukakan oleh Charles Sanders Pierce mengenai ikon, indeks, dan simbol, serta teori semiotika yang dikemukakan oleh Roland Barthes mengenai kode-kode semiotika. Pendekatan tersebut mencakup pada analisis terhadap tanda-tanda verbal dan visual, sehingga dapat diketahui 
makna-makna konotasi yang ada pada logo video game tersebut.

Dari keseluruhan populasi yang ada, setelah diambil ke-tiga sampel secara purposive sampling, pemilihan sampel yang ada didasarkan pada kriteria-kriteria khusus yang dapat mewakili keseluruhan populasi yang ada. Pada penelitian ini, logo video game The Last Story merupakan suatu logo yang unik dengan suatu konsep desain yang berbeda dibandingkan logo-logo lain yang didapati di era modern ini. Apabila kebanyakan dari konsep logo pada tahun 2000-2015 yang ditemukan di lapangan, yang mana digunakan sebagai logo komersial cenderung menggunakan konsep logo yang sederhana (simplicity) untuk memaksimalkan kejelasan (clarity) pada sisi visual sehingga memiliki tingkat mobilitas fungsi logo yang tinggi, pada desain logo video game The Last Story ini tidak dipahami memiliki konsep desain yang sama seperti logo-logo era 20002015.

Dari penggunaan teori-teori semiotika yang ada sebagai dasar teori untuk analisis, logo video game The Last Story lebih mengedepankan sisi komunikasi secara visual yang lebih menyeluruh, dapat dilihat pada sampel desain logo publikasi yang dikeluarkan oleh Mist Walker. Antara tipografi, ilustrasi karakter serta penggunaan ilustrasi background saling tampak saling melengkapi satu-sama lain sebagai tandatanda (verbal dan visual) yang memiliki makna konotasi yang berbeda namun saling berkaitan.

Pada tipografi yang digunakan, secara subtle (tidak tampak di permukaan) mengkomunikasikan dua hal, secara verbal hasil analisis menunjukkan bahwa sense penamaan pada video game ini mengkomunikasikan kepada audience bahwa game The Last Story merupakan game master piece yang dikembangkan oleh Mist Walker, sedangkan pada analisa style yang ada dari tipografi secara visual tipografi ini mengkomunikasikan kandungan tema cerita yang ada pada game. Pada ilustrasi karakter yang mendampingi tipografi, ditemukan adanya kaitan langsung antara cerita yang ada pada game, konflik yang terjadi, dan filosofi yang muncul pada game itu sendiri. Sosok Calista pada ilustrasi logo seolah menjadi kunci komunikasi developer game saat hendak berkomunikasi dengan audience dengan cara bercerita secara visual melalui tanda-tanda yang ada yang dapat menjawab pertanyaan mengenai kisah yang ada pada game. Dengan tanda-tanda yang dihadirkan melalui ilustrasi ini mempermudah pemahaman makna konotasi oleh audience yang muncul dalam benak sebagai bagian dari imajenasi/konsep 
berfikir visual sebagaimana suatu buku dengan ilustrasi, sehingga terbayangkan halhal apa yang muncul pada game The Last Story ini. Sedangkan sisi background yang ada, menjadi sebuah pendamping yang penting yang disertakan pada logo sebagai bagian komunikasi visual dan verbal yang pada tanda-tandanya menguak sisi konseptual dan ideologi yang ada pada game dan developer game.

Logo publikasi versi Jepang memiliki aksara Jepang katakana pada bagian bawahnya, memiliki tujuan untuk kemudahan keterbacaan bagi orang Jepang disamping konotasinya untuk menunjukkan identitas publisher Mist Walker yang berasal dari Jepang dan juga menunjukkan bahwa game yang dihasilkan tersebut memiliki dua bahasa yang dapat dipilih berdasarkan versinya. Pada sisi lain, kekurangan yang dimiliki oleh logo publikasi secara fungsional adalah kurangnya mobilitas logo, sampel logo cover pada sisi lain menjadi penyeimbang, menutupi kekurangan yang dimiliki oleh logo publikasi, dan hal ini juga berlaku sama pada variasi logo lainnya. Sifat ini kemudian menjadikan munculnya konotasi pada logo, bahwa game yang ada tersebut adalah game yang seimbang tingkat kesulitannya tidak mempersulit player namun juga tidak terlalu mudah, dan juga tiap kekurangan yang ada pada game selalu diperbaiki atau diganti dengan yang lebih baik dan lebih sesuai.

\section{KESIMPULAN}

Dari hasil analisis tersebut selanjutnya dapat dipahami bahwa perusahaan Mist Walker, menggunakan logo publikasi yang tidak main stream sebagai logo utama game The Last Story sebagai pemikat yang berkomunikasi dengan gamers sebagai target audience. Logo pada umumnya merupakan alat komunikasi yang didesain sesederhana mungkin untuk memecahkan masalah branding dengan kesederhanaan komunikasi (sehingga mudah diingat pada saat dilihat dalam jeda waktu yang relatif pendek), logo video game The Last Story justru kaya akan pesan yang disampaikan oleh tanda-tandanya. Perbandingannya jika promosi suatu produk, logo modern pada umumnya tampak seperti katalog dalam bentuk flyer, maka logo video game The Last Story tampak seperti katalog dalam bentuk buku. Sehingga tiap-tiap keunggulan produknya dipamerkan pada logo, tidak sekedar mengedepankan filosofi logo tetapi juga mampu berbicara dan bercerita terhadap hal-hal penting yang ada pada game tersebut melalui tanda-tanda yang ada pada logo yang dapat dipahami melalui semiotika.

Pada penelitian semiotika ini, peneliti menemukan bahwa komunikasi yang terjadi 
dari suatu objek desain komunikasi visual terhadap audience sifatnya subyektif, tergantung dari sejauh mana audience dapat mengenali dan memahami tanda-tanda yang ada. Adanya bantuan teori semiotika dari tokoh semiotika semisal Ferdinand de Saussure, Charles Sanders Pierce dan Roland Barthes dapat membantu melihat objek desain komunikasi visual tersebut dengan lebih mendalam, tidak hanya pada permukaan saja, sehingga makna-makna konotasi level lanjutan dapat ditemukan. Hal ini berkaitan dengan sejauh mana referensi yang dimiliki oleh peneliti terhadap informasi dan cabang ilmu lain, semakin banyak referensi yang dimiliki maka akan semakin banyak makna yang dapat ditemukan dan dipilah untuk disesuaikan dengan teks dan konteks yang ada.

Bagi perusahaan komersial, ternyata logo saat dimanfaatkan sebagai karya desain komunikasi visual tidak harus mengikuti standar kesederhanaan sebagaimana logo komersil pada umumnya, sebaliknya logo yang berkesan rumit terkadang justru memiliki sisi kelebihan yang tidak dimiliki oleh logo yang sederhana. Penggunaan logo yang penuh dengan tanda-tanda biasanya digunakan pada emblem atau lambang kenegaraan dan dianggap sebagai pemecahan solusi yang klasik yang tidak cocok untuk modern ini ternyata tidak sepenuhnya benar, suksesnya video game The Last Story yang menggunakan logo dengan konsep serupa menjadi semacam bukti bahwa anggapan tersebut tidak sepenuhnya benar. Apabila terdapat permasalahan pada mobility/versatility pada logo, maka logo dapat dibuatkan versi lain yang lebih sederhana namun dapat tetap mewakili dan diasosiasikan dengan objek yang diwakili, dan hal inilah yang dilakukan oleh perusahaan Mist Walker dalam mengkomunikasikan video game The Last Story kepada audience

\section{DAFTAR PUSTAKA}

[1] Abe, Sachiko. 1990. New Easy Japanese Conversation \& Grammar. Singapura: Abe Publishing House.

[2] Anggraini, Lia, Nathalia, Kirana. 2014. Desain Komunikasi Visual, Dasar-Dasar Panduan Untuk Pemula. Bandung: Nuansa Cekendia.

[3] Berger, Arthur Asa. 2010. Tanda-tanda dalam kebudayaan kontemporer. Terjemahan M. Dwi Marianto. Yogyakarta: Tiara Wacana.

[4] Budiman, Kris. 2004. Semiotika Visual. Yogyakarta : Buku Baik.

[5] Bungin, Burhan. 2003. Analisis Dat Penelitian Kualitatif. Jakarta: RajaGrafindo Persada.

[6] Ebdi Sanyoto, Sadjiman.2009. Nirmana, Elemen-elemen Seni dan Desain. Yogyakarta:Jalasutra.

[7] H.Hoed, Benny. 2011. Semiotik \& Dinamika Sosial Budaya. Depok: Komunitas Bambu.

[8] Kusrianto, Adi. 2007. Pengantar Desain komunikasi Visual. Yogyakarta: Andi. 
[9] Lip, Evelyn. 1996. The Design \& Feng Shui of Logos, Trademark \& Signboards. Terjemahan Sindhi Dia Savira. Jakarta: PT. Elex Media Komputindo.

[10] Sobur, Alex. 2009. Semiotika Komunikasi. Bandung: Penerbit Rosda.

[11] Tinarbuko, Sumbo. 2009. Semiotika Komunikasi Visual. Yogyakarta: Jalasutra.

[12] Trefil, James dan M. Hazen, Robert. 2007. The Science An Integrated Approach 5E. Amerika Serikat: Von Hoffmann Corporation.

[13] Ratna Kustanti, Maulina. 2007. Studi Logo Perguruan Tinggi Negeri Di Indonesia Yang Mengandung Ikonografi Hindu Ditinjau Dari Aspek Mitologi. Yogyakarta: Institut Seni Indonesia Yogyakarta.

[14] Putra, Dimach Oktaviansyah Karunia. 2013. Kajian Semiotika Komunikasi Visual Guna Membaca Kartu The Fool, The Magician, The High Priestess, The Lovers, Wheel of Fortune. Yogyakarta: Institut Seni Indonesia Yogyakarta.

[15] Rahandono, Ikhsan. 2014. Kajian Semiotika Iklan Pemenang Cannes Lions International Advertising Festival Versi Print ADS Tahun 2013. Yogyakarta: Institut Seni Indonesia Yogyakarta.

[16] Hapsari, Mirah. 2013. Studi Makna Konotasi Iklan Luar Ruang Rokok Produk PT. Djarum : Kajian Semiotika Iklan Luar Ruang. Yogyakarta: Institut Seni Indonesia Yogyakarta.

[17] Barthes, Roland. 1967. Elements of Semiology. Terjemahan Jonatha Cape. New York: Hill \& Wang.

[18] Barthes, Roland. 1974. S/Z. Terjemahan Richard Miller. New York: Hill \& Wang.

[19] DeVito, A. Joseph. 2002. Human Communication. Boston: Allyn \& Bacon.

[20] W. Cre swell, John. 2000. How SAGE has shaped Research Methods, A 40 Year History. University of Nebr aska-Lincoln.
[21] Megg, Philip B. 2012. Meggs' History of Graphic Design. New Jersey: John Wiley \& Sons.

[22] R. Gibbs, Grahan. 2007. Analyzing Qualitative Data. London: SAGE Publication Ltd.

[23] Sean Adams \& Noreen Morioka. Logo Design Workbook: a hands-on guide to creating logos. Massachusetts: Rockport Publisher.

[24] Catatan oleh Sumbo Tinarbuko. 20142015. Institut Seni Indonesia Yogyakarta.

[25] Catatan Perkuliahan oleh Ryan Aditya P. W. 2010-2013. Institut Seni Indonesia Yogyakarta.

[26] B. Rohrer, Steven. 2011. Why Do Japanese People Not Speak English?, Japanese.

[27] Behind the Scenes at Coleco and Atari. Majalah Video Games. Edisi K48964. Juni 1983.

[28] Elementary Students in a Bilingual School. Cedarville : Cedarville University

[29] International Trademark Association : A Guide To Proper Trademark Use - For Media, Internet and Publishing.

[30] Paten Amerika Serikat. No. 3659285.

[31] Square Enix: 2004 Annual Report, 06 Agustus 2004:15.

[32] Trademark Law Treaty : Geneva pada 27 Oktober 1994.

\section{PERTAUTAN}

[1] http://cahyosetiadi.wordpress.com/2010/ 02/08/analisis-naratif/.

Diakses: 28/03/2014, 15:22.

[2] http://en.wikipedia.org/wiki/Charles_San ders_Peirce. Diakses: 06/03/2015, 02:35.

[3] http://en.wikipedia.org/wiki/Ferdinand_ de_Saussure. Diakses: 06/03/2015, 02:31.

[4] http://en.wikipedia.org/wiki/Roland_Bar thes. Diakses: 06/03/2015, 02:37.

[5] http://en.wikipedia.org/wiki/The_Last_St ory. Diakses: 28/03/2014 15:21. 
[6] http://httpcdn-uploads.gameblog.fr. Diakses: 18/03/2015, 07:04.

[7] http://laststory.wikia.com/wiki/Story. Diakses: 22/05/2014, 13:12.

[8] http://microsite.nintendo-europe.com. Diakses: 28/02/2015, 05:34.

[9] http://operationrainfall.com/the-laststory-releases-on-august-14th-2012/. Diakses: 17/05/2014, 11:39.

[10] http://torontopast.wordpress.com. Diakses: 31/02/2015, 07:16.

[11] http://web.archive.org/web/20090226064 943/http://time.com/time/covers/110105 0523/console_timeline. Diakses: 16/05/2013, 23:13.

[12] http://www.about-garden.com/. Diakses: 12/06/2015, 04:12.

[13] http://www.capsulecomputers.com.au. Diakses: 26/04/2015, 03:01.

[14] http://www.consolewatcher.com/2006/05 /nintedo-revolution-renamed-tonintendo-wii/. Diakses: 16/05/2013, 23:15.

[15] http://www.creativeuncut.com/art_thelast-story_a.html. 16/02/2013, 12:06.

[16] http://www.finalfantasy-fxn.net. Diakses: 08/05/2015, 10:02.

[17] http://www.gamingunion.net/features/95 7/the-last-story-yet-another-finalfantasy/. Diakses: 31/05/2014, 05:32.

[18] http://www.giantbomb.com/mistwalkercorporation/3010-6286/. Diakses: 28/03/2014, 15:22.

[19] http://www.ign.com. Diakses 08/05/2015, 10:00.

[20] http://www.logodesignbizz.com. Diakses: 19/04/2015, 17:32.

[21] http://www.logodesignlove.com/atarilogo. Diakses: 31/12/2014, 09:54.

[22] http://www.nintendo.co.uk/Iwata-Asks. Diakses: 26/05/2015, 09:23.

[23] http://www.oxforddictionaries.com. Diakses: 02/02/2015, 11:42.
[24] http://www.pongstory.com/odyssey.htm. Diakses: 31/12/2014, 06:32.

[25] http://www.thelaststorywii.com. Diakses: 02/02/2015, 11:42.

[26] http://www.youtube.com/watch? $\mathrm{v}=\mathrm{m} 0 \mathrm{U}$ Ne8bNfEo. Diakses: 27/05/2015, 07:37.

[27] htttp://www.mistwalker-fr.info. Diakses: 28/02 2014, 04:50. 